Article

\title{
Christianity, Antisemitism, and the Holocaust
}

\author{
Henry Munson \\ Department of Anthropology, University of Maine, Orono, ME 04469, USA; henry.munson@maine.edu \\ Received: 7 December 2017; Accepted: 12 January 2018; Published: 16 January 2018
}

\begin{abstract}
There is, in principle, a fundamental difference between Nazi racial antisemitism and the traditional anti-Judaism of Christianity. The church's official view has been that conversion transforms a Jew into a Christian, whereas the Nazi view was that a Jewish convert to Christianity remained a Jew. Nevertheless, the distinction between racial and religious antisemitism has often been less clear-cut than is often claimed by those who claim that Christian churches bear no responsibility for the Holocaust. That is not to say that it is illusory, just that it has often been less clear-cut than is often claimed. During the Holocaust and the decades that preceded it, Christian clergy often stressed the same themes as the Nazis, notably with respect to the Jews being "parasitic" capitalists exploiting Christians, as well as communists seeking to overthrow the governments and traditional Christian values of Europe (Passelecq and Suchecky 1997, pp. 123-36). We shall see that these clerics often also spoke of Jews in racial, as well as religious terms. Conversely, the Nazis often exploited traditional Christian themes, such as the diabolical nature of the Jew, the image of the Jew as "Christ-killer," and the contrast between "carnal" (materialistic) Judaism and spiritual Christianity. In other words, the Nazis effectively exploited two millennia of Christian demonization of the Jew. Most scholars who have studied the role of the Christian churches during the Holocaust are well aware of most of these facts (Barnett 1992; Bergen 1996; Ericksen and Heschel 1999a; Kertzer 2001). Yet many comparative studies of religion and violence ignore the role played by Christian churches during the Holocaust-apparently on the assumption that the most horrific mass murder in human history was a purely secular phenomenon. In fact, some prominent scholars, including the best-selling authors Karen Armstrong and-incredibly-Rabbi Jonathan Sacks, go so far as to attribute the Shoah to the demise of religious values in Europe (Armstrong 2014; Sacks 2015)! This article is an attempt to correct these mistaken assumptions.
\end{abstract}

Keywords: Christianity; antisemitism; Holocaust

\section{Introduction}

In her 2014 book Fields of Blood: Religion and the History of Violence, Karen Armstrong writes:

Born of modern scientific racism, the Holocaust was the ultimate step in social engineering and the most extreme demonstration of the inability of the nation to tolerate minorities. It showed what can happen once the sense of the sacredness of every single human being-a conviction at the heart of traditional religions that quasi-religious systems seem unable or disinclined to re-create-is lost (Armstrong 2014, p. 341). ${ }^{1}$

Armstrong, a former nun, thus portrays the Holocaust, or Shoah, as the result of "modern scientific racism" and the erosion of the traditional religious notion of "the sacredness of every single human

1 Armstrong does write on pp. 298-99 of Fields of Blood that "the new anti-Semitism drew on centuries of Christian prejudice but gave it a scientific rationale," but she ignores this point in her statement about the Holocaust being "born of modern scientific racism." 
life." This argument is reminiscent of that made by the Roman Catholic Church in its 1998 statement "We Remember: A Reflection on the Shoah" (Kertzer 2001, pp. 3-4). ${ }^{2}$ Aside from the obvious fact that the racism of the Nazis and their fascist allies was pseudoscientific rather than scientific, Armstrong ignores the fact that religions, including Christianity, traditionally tended to view only the lives of the members of their own group as sacred, while the members of other religious groups were typically seen as subhuman or demonic and, thus, eminently killable (Munson 2005). Armstrong also ignores the extensive scholarly literature demonstrating that many churches either enthusiastically supported the regimes that carried out the mass murder of the Jews, or at the very least, did not publicly condemn them (Ericksen and Heschel 1999a; Paldiel 2006). She ignores the fact that many of the regimes that helped Nazi Germany carry out the mass murder of the Jews had an explicitly Christian orientation (Feldman et al. 2008; Paldiel 2006). She ignores the extensive scholarly literature demonstrating that the line between racial and religious antisemitism was often a porous and malleable one (Heschel 2011; Kertzer 2001). Additionally, she ignores the fact that close to two millennia of Christian demonization of the Jew encouraged Europe's Christians to accept Nazi demonization of the Jew (Bergen 1996, p. 191). This is not to say that traditional Christian hostility toward the Jew entailed the Holocaust. It did not, but it certainly helped make it possible (Katz 1994, pp. 227, 235, 315-17, 399-400).

Rabbi Jonathan Sacks takes a position similar to Armstrong's in his book Not in God's Name: Confronting Religious Violence (Sacks 2015):

The Nazi ideology was not religious. If anything, it was pagan. It was also based on ideas that were thought at the time to be scientific: the so-called 'scientific study of race' (a mixture of biology and anthropology) and 'social Darwinism', the theory that the same processes operating in nature operate in society also. The strong survive by eliminating the weak (p. 54).

Sacks, the former Chief Rabbi of the United Hebrew Congregations of the British Commonwealth, stresses that "Nazism had nothing to do with religion" (p. 65) and "the Holocaust was not the result of Christianity; it is important to state this categorically at the outset" (p. 90). Like Armstrong, Sacks sees the Holocaust as the demise of religious values that resulted from the Enlightenment:

As European culture became secularised and religious anti-Judaism mutated into racial antisemitism, the consequences were lethal. Christians could work for the conversion of the Jews, because you can change your religion. However, you cannot change your blood or your genes. Antisemites could therefore only work for the elimination of the Jews. The result was the Holocaust (pp. 79-80).

Every attempt to find a substitute for religion has resulted in even more violence. Nationalism led to two world wars. Political ideology led to Lenin and Stalin. Race led to Hitler and the Holocaust. The result was the bloodiest century in human history (p. 101).

Referring specifically to the Enlightenment, Sacks writes:

Science and philosophy would, people thought, succeed where religion and revelation had failed. They would unite humankind in what Kant called 'perpetual peace'. The reaction to this, a century later, was the emergence of nationalism, racism and communism, two world wars, the Holocaust and the Gulag (pp. 190-91).

The arguments made by Armstrong and Sacks are not uncommon. They can be found in most defenses of religion in the late twentieth and early twenty-first centuries (Brog 2010, p. 169; Hedges 2008, p. 19;

2 "We Remember" is available online at http:/ / www.vatican.va/roman_curia/pontifical_councils/chrstuni/documents/rc_ pc_chrstuni_doc_16031998_shoah_en.html (accessed on 31 December 2017). 
Limbaugh 1992, p. 281). It is certainly true that the Shoah was not exclusively, or even primarily, caused by traditional Christian hostility toward the Jew. However, the notion that the Holocaust occurred because Germany, and Europe in general, sought to find a secular substitute for religion does not provide an accurate picture of the role played by Christianity and Christian churches during the mass murder of the Jews in Christian Europe.

\section{The Demonization of the Jew in the New Testament}

For almost two millennia, the Jew played a key role in the central myth of Christianity-that of the materialistic, hypocritical, spiritually-blind, and diabolical "Christ-killer." One thinks of New Testament verses like the following (King James Version) that were, as we shall see, often quoted or alluded to by both Nazis and antisemitic Christian clerics:

Gospel of Matthew:

21:12-13 And Jesus went into the temple of God, and cast out all them that sold and bought in the temple, and overthrew the tables of the moneychangers, and the seats of them that sold doves, And said unto them, It is written, My house shall be called the house of prayer; but ye have made it a den of thieves.

23:29-33 Woe unto you, scribes and Pharisees, hypocrites! because ye build the tombs of the prophets, and garnish the sepulchres of the righteous, And say, If we had been in the days of our fathers, we would not have been partakers with them in the blood of the prophets. Wherefore ye be witnesses unto yourselves, that ye are the children of them which killed the prophets. Fill ye up then the measure of your fathers. Ye serpents, ye generation of vipers, how can ye escape the damnation of hell?

27:24-25 When Pilate saw that he could prevail nothing, but that rather a tumult was made, he took water, and washed his hands before the multitude, saying, I am innocent of the blood of this just person: see ye to it. Then answered all the people, and said, His blood be on us, and on our children.

Gospel of John:

5:18 Therefore the Jews sought the more to kill him, because he not only had broken the sabbath, but said also that God was his Father, making himself equal with God.

8:44 Ye are of your father the devil, and the lusts of your father ye will do.

Since the Holocaust, there have been countless attempts by both Jews and Christians to drain the venom from such verses, with particular emphasis on the fact that Jesus and the first Christians were themselves Jews (Berger 2015; Levine 2006). However, this is definitely not how the Nazis and their Christian supporters interpreted the New Testament.

\section{Nazi Exploitation of Traditional Christian Demonization of the Jew}

Hitler and other Nazis made abundant use of the traditional Christian image of the Jew as a materialistic and diabolical "Christ-killer." One can argue that they often did so simply to win support for their essentially secular racist plan to eradicate the Jews of Europe. ${ }^{3}$ Assuming this is true, it simply demonstrates that they knew that the traditional Christian image of the Jew still played

3 The issue of how Hitler and other prominent Nazis really viewed Christianity is discussed in Richard Steigmann-Gall (2003) The Holy Reich: Nazi Conceptions of Christianity, 1919-1945, in the various critiques of this book in the January 2007 issue of the Journal of Contemporary History, and in Steigmann-Gall's response to his critics in the April 2007 issue of this same journal: (Bergen 2007; Gailus 2007; Hexham 2007; Piper 2007; Steigmann-Gall 2007). 
an important role in the popular Christian imagination. Ninety-seven percent of Germans had been raised as Christians and remained affiliated with a Christian church when Hitler came to power in 1933 (Ericksen 2012, p. 9) Even after six years of Nazi rule, the German census of May 1939 found that only 1.5 percent of Germans considered themselves "unbelievers." Thus, while some Nazi leaders were undoubtedly hostile to Christianity, the Nazi regime generally tried to avoid antagonizing the Catholic and Protestant churches unnecessarily. Thus, the Third Reich continued to fund Protestant and Catholic churches until its demise in 1945 (Ericksen and Heschel 1999b, p. 10; Ericksen 2012, p. 9).

Article 24 in the Nazi Party Program of 1920 endorsed what it called "positive Christianity":

We demand freedom for all religious confessions in the state, insofar as they do not endanger its existence or conflict with the customs and moral sentiments of the Germanic race. The party as such represents the standpoint of a positive Christianity, without tying itself to a particular confession. It fights the spirit of Jewish materialism within us and without us, and is convinced that a lasting recovery of our Volk can only take place from within, on the basis of the principle: public need comes before private greed (Steigmann-Gall 2003, p. 14).

The notion of "positive Christianity" was intended to transcend Protestant-Catholic tensions as well as to demonstrate that the National Socialist movement should not be seen as hostile to Christianity-even though some of its most prominent leaders were.

Hitler ended Mein Kampf with a tribute to his mentor Dietrich Eckart, who wrote in his final book Bolshevism from Moses to Lenin: a Conversation between Adolf Hitler and Myself (published in 1923, the year of Eckart's death): "Christ stands never otherwise than erect, never otherwise than upright ... eyes flashing in the midst of the creeping Jewish rabble...and the words fall like lashes of the whip: 'Your father is the devil' (John 8:44)" and "In Christ, the embodiment of all manliness, we find all that we need" (Steigmann-Gall 2003, pp. 17-18).

In 1921, Hitler told a National Socialist rally:

Those who want to keep our Christianity, which, alas, today is merely a Christianity of appearances rather than one of deeds, have to confront those who rob us of our Christianity ... . We may be small, but a man once stood up in Galilee and today his teachings dominate the whole world. I cannot imagine Christ but blond and blue-eyed. The devil I can only imagine with the Jewish grimace (Bucher 2011, p. 28).

In a speech Hitler gave at a National Socialist meeting on 12 April 1922, he elaborated on his view of Jesus as a fighter against diabolical Jews:

I SAY: MY FEELING AS A CHRISTIAN POINTS ME TO MY LORD AND SAVIOUR AS A FIGHTER. IT POINTS ME TO THE MAN WHO ONCE IN LONELINESS, SURROUNDED ONLY BY A FEW FOLLOWERS, RECOGNIZED THESE JEWS FOR WHAT THEY WERE AND SUMMONED MEN TO THE FIGHTAGAINST THEM AND WHO, GOD'S TRUTH! WAS GREATEST NOT AS SUFFERER BUT AS FIGHTER. In boundless love as a Christian and as a man I read through the passage which tells us how the Lord at last rose in His might and seized the scourge to drive out of the Temple the brood of vipers and of adders. How terrific was His fight for the world against the Jewish poison. Today, after two thousand years, with deepest emotion I recognize more profoundly than ever before the fact that it was for this that He had to shed His blood upon the Cross. As a Christian I have no duty to allow myself to be cheated, but I have the duty to be a fighter for truth and justice. And as a man I have the duty to see to it that human society does not suffer the 
same catastrophic collapse as did the civilization of the ancient world some two thousand years ago-a civilization which was driven to its ruin through this same Jewish people. ${ }^{4}$

In Mein Kampf, Hitler declared: "In standing guard against the Jew I am defending the handiwork of the Lord." ${ }^{5}$ Elsewhere in the same work, he wrote:

... the Founder of Christianity made no secret indeed of His estimation of the Jewish people. When He found it necessary He drove those enemies of the human race out of the Temple of God; because then, as always, they used religion as a means of advancing their commercial interests. However, at that time Christ was nailed to the Cross for his attitude towards the Jews; whereas our modern Christians enter into party politics and when elections are being held they debase themselves to beg for Jewish votes. ${ }^{6}$

In a speech given on 15 February 1933, two weeks after taking power, Hitler responded to the charge that his regime threatened Christianity by saying: "In the first place it is Christians and not international atheists who now stand at the head of Germany. I do not merely talk of Christianity, no, I also profess that I will never ally myself with the parties which destroy Christianity." In a speech on 23 March 1933, Hitler declared that "the Government of the Reich, which regards Christianity as the unshakable foundation of the morals and moral code of the nation, attaches the greatest value to friendly relations with the Holy See." ${ }^{7}$ Such explicit assertions that the Third Reich would be based on Christianity became rarer after Hitler and the Nazis consolidated their hold on power. However, Hitler never publicly repudiated them and, as we shall see, many Christian clerics did, in fact, see Hitler as a defender of Christian morality.

Hitler was by no means the only Nazi to invoke the central themes of classical Christian hostility toward the Jew. In 1936, Julius Streicher, editor of the pro-Nazi tabloid Der Stürmer, gave a Christmas speech to two thousand children. He asked his young listeners: "Do you know who the Devil is?" The children responded without hesitation: "The Jew, the Jew" (Goldhagen 2002, p. 139). At his trial in Nuremberg in 1946, Streicher argued that Martin Luther should be on trial with him given his condemnation of the Jews in the sixteenth century (Goldhagen 2002, p. 163).

In 1938, Der Stürmer's publishing house published a children's book entitled The Poisonous Mushroom (Der Giftpilz) by Ernst Hiemer with pictures by the cartoonist/illustrator Philipp Rupprecht (also known as Fips). Chapter 13 is entitled "What Christ said about the Jews." It begins with a picture of a blonde peasant woman and two blonde children looking up at a large crucifix. A blonde baby sleeps in a crib at the foot of the cross. Under the picture is the caption in large bold letters: "When you see a cross, remember the gruesome act of murder committed by the Jews on Golgotha."

The chapter reads as follows:

A peasant mother returning from field work, with her three children, pauses before a wayside Christ. The mother talks to them about the wickedness of the Jews.

She points to the cross, which stands by the road:

Children, look there! The man who hangs on the cross was one of the greatest enemies of the Jews of all time. He knew the Jews in all their corruption and meanness. Once he drove the Jews out with a whip, because they were carrying on their money dealings in the church. He called the Jews: Killers of men from the beginning. By that he meant that the

4 https://archive.org/stream/TheSpeechesOfAdolfHitler19211941/hitler-speeches-collection_djvu.txt. See also (Bucher 2011, p. 77). I have used the upper-case letters in the djvu version. Bucher only has "my feeling as a Christian points me to my Lord and Saviour as fighter" in italics.

5 http://gutenberg.net.au/ebooks02/0200601.txt, last sentence of Mein Kampf, vol. 1, chp. II.

6 http://gutenberg.net.au/ebooks02/0200601.txt, Mein Kampf, vol. 1, chp. XI.

7 https://archive.org/stream/TheSpeechesOfAdolfHitler19211941/hitler-speeches-collection_djvu.txt. 
Jews in all times have been murderers. He said further to the Jews: Your father is the Devil! Do you know, children, what that means? It means that the Jews descend from the Devil. And because they descend from the Devil they can but live like devils. So they commit one crime after another.

The children look thoughtfully at the cross. Mother continues:

Because this man knew the Jews, because he proclaimed the truth to the world, he had to die. Hence the Jews murdered him. They drove nails through his hands and feet and let him slowly bleed. In such a horrible way the Jews took their revenge. And in a similar way they have killed many others who had the courage to tell the truth about the Jews. Always remember these things, children. When you see the cross, think of the terrible murder by the Jews on Golgotha. Remember that the Jews are children of the Devil and human murderers. ${ }^{8}$

Once again, these examples do not prove that Hitler and other leading Nazis were primarily motivated by traditional Christian hostility toward the Jew, just that they realized that such hostility remained deeply embedded in the popular Christian imagination and that they could exploit it to gain support for their anti-Semitic policies.

\section{Germany's Protestants and the Holocaust}

Those who argue that Christianity bears no responsibility for the Holocaust generally emphasize the distinction between the racial antisemitism of the Nazis and traditional Christian hostility toward the Jew. The former is said to have resulted in the Holocaust, not the latter. Those who make such arguments do not usually discuss groups like the German Christian movement, which won two-thirds of the votes cast in Germany's Protestant church elections on 23 July 1933-thanks in part to strong support from Hitler. After these elections, the German Christians controlled all but three of the bishoprics of Germany's regional Protestant churches and most of the theology schools in German universities (Bergen 1996, pp. 5-7). Doris Bergen (1996), the author of Twisted Cross: The German Christian Movement in the Third Reich writes:

... the German Christians maintained a significant presence throughout the years of National Socialist rule. For more than a decade they sustained a mass movement of over half a million members with branches in all parts of Germany. Adherents held important positions within Protestant church governments at every level and occupied influential posts and theological faculties and religious training institutes. From those offices, they controlled many of the decisions and much of the revenue of the Protestant church. The movement's quest to fuse Christianity and National Socialism reflected the desire of many Germans to retain their religious traditions while supporting the Nazi fatherland. Throughout the 1930s and during the war years, German Christian women and men held rallies, attended church services, and published newspapers, books and tracts. They sang hymns to Jesus but also to Hitler. Through sermons, speeches, and songs they propagated anti-Jewish Christianity and boosted Nazi racial policy. After the Third Reich collapsed in 1945, instead of being ostracized in their congregations and shut out of ecclesiastical posts, German Christians, lay and clergy, found it relatively easy to integrate into Protestant church life.

(Bergen 1996, p. 2)

8 https://www.mtholyoke.edu/courses/rschwart/hist151/Nazi/poisonousmushroom.pdf, last accessed 29 November 2017. This passage is also quoted by Gregory Paul Wegner in Anti-Semitism and Schooling under the Third Reich (Wegner 2002, p. 365). Wegner discusses The Poisonous Mushroom and other Nazi school books that invoked traditional Christian notions of the Jew, especially in Chapter 5: "Exemplars of Anti-Semitic Literature for Children" (pp. 354-405). 
The German Christian movement actually consisted of a number of movements that sought to synthesize National Socialism and Christianity and, thus, racial and religious antisemitism, from the 1920s through the mid-1940s (Solberg 2015, pp. 14, 17, 44). In February 1934, a Gestapo agent described a German Christian meeting in Berlin, at which three clergymen, including one member of the Nazi party, addressed the crowd. One of the clergymen declared, "They say that everyone is equal before God. However, baptism never made a Jew into a German, nor did it ever straighten a crooked hook-nose ... . We want a Christianity that is true to our race" (Bergen 1996, p. 22).

In a text entitled German Christians: A People's Book, A Guide to Today's Faith Movement published in 1934, Hitler's accession to power is described as "the great experience":

And now it is our responsibility, with the strength and enthusiasm this great experience gives us, to build up our spiritual world, with all our hearts to be both German and Christian, to be German Christians.

This is what the Führer wants. He, the most German man, is also the most faithful, a believing Christian. We know that he begins and ends the course of his day with prayer, that he has found in the Gospel the deepest source of his strength (Solberg 2015, p. 302).

There is no evidence that Hitler actually did begin and end each day with a prayer or that he "found in the Gospel the deepest source of his strength." However, this is how the German Christians perceived him, as a man of God, and as the leader (führer) sent by God to liberate the German people from their enemies, especially the Jews.

In 1935, Siegfried Leffler (1900-1983) a Lutheran pastor and a leader of the German Christian movement, published Christ in Germany's Third Reich: The Nature, the Path, and the Goal of the German Christian Church Movement. We find the following passages in this work:

In the person of the Führer we see the one God has sent, who sets Germany before the Lord of history, who calls us from the worship of words, from the cult of the Pharisees and the Levites, to the holy service of the Samaritan ...

$\ldots$ in the pitch-black night of Christian church history, Hitler became

like a wonderful transparency for our time, a window through which light fell upon the history of Christianity. Through him we were able to see the Savior in the history of the Germans. Hitler stood there like a rock in a broad wilderness, like an island in an endless sea. ... (Solberg 2015, pp. 346-47)

Referring to "the people Israel," Leffler writes:

As a people it became a Satanic curse for the world when it decided against the God of heaven and earth and crucified him in Christ his Son....

Wherever they live-whether in Japan, in Germany, or in

America-whether they were the most liberal Jews in Western

Europe or the most orthodox Zionists in Tel Aviv or Bethany, they remained one people with one pulse, one will, one world-goal. They forced virtually the whole world to obey the laws of their way of thinking and acting; their spirit infected the thinking of all other peoples and in this way destroyed their cohesion (Solberg 2015, pp. 347-49).

Leffler refers to Jesus as "the most positive antisemite of all time" (Solberg 2015, p. 351) He then turns to a common theme in the German Christian literature, the idea that God sent both Martin Luther and Adolf Hitler to the German people and that Hitler is completing the national/religious reformation that Luther began: 
In Martin Luther we received the spiritual foundations of German Christianity. We should have eyes to see this and-in the hour of grace that the eternal

Lord has granted us through Adolf Hitler-to meet the challenge

Luther's redemptive act presents, but that could not be met during

his own time: to become a community of German Christians.... Just as with Hitler today, so also it was clear with Martin Luther in the sixteenth century that a man sent by God has an impact on all areas and all people.... we cannot imagine Adolf Hitler without Martin Luther. And vice versa: without the appearance of Adolf Hitler four hundred years later, Martin Luther's act would not have fulfilled its total significance for Germany (Solberg 2015, pp. 353-57).

The author of these lines, Siegfried Leffler, joined the Nazi Party in 1929 and remained a leader of the German Christian movement throughout the Third Reich. After Germany's defeat, he continued to preach the word of God as a pastor in Bavaria from 1949 until 1970 (Heschel 2008, p. 249).

With specific reference to the issue of race, it played a central role in German Christian rhetoric. In "The Original Guidelines of the German Christian Faith Movement" written by Pastor Joachim Hossenfelder and published in 1932, before Hitler had come to power, we read the following:

We recognize in race, ethnicity [Volkstum], and nation orders of life given and entrusted to us by God, who has commanded us to preserve them. For this reason race-mixing must be opposed. Based on its experience, the German foreign mission has long admonished the German people: "Keep your race pure!" and tells us that faith in Christ does not destroy race, but rather deepens and sanctifies it. ... In the mission to the Jews we see great danger to our people. It is the point at which foreign blood enters the body of our people.... We reject the mission to the Jews as long as Jews have citizenship, which brings with it the danger of race-blurring and race-bastardizing ... It is especially important to prohibit marriages between Germans and Jews (Solberg 2015, pp. 49-50).

One of the most common terms in the German Christian lexicon (and in that of National Socialism) was Volk. A 1937 pamphlet defines this word as follows: "Volk" is the divinely willed community of German people based on the created orders of race, blood, and soil [Rasse, Blut und Boden]. This same pamphlet declares "The German church's duty is to serve the German Volk with the power of the Gospel. Service to the Volk is service to God (Solberg 2015, p. 402). During Advent (the four Sundays and weeks before Christmas) in 1935, a German Christian pastor urged the members of his congregation to light candles in their windows that would announce: "A Christian lives here. In this home, we pray for Führer and Volk!" (Bergen 1996, p. 48). It is somewhat difficult to see the distinction between religious and racial antisemitism in all of this.

It is true that not all German Protestants supported the German Christians. The movement that came to be known as the Confessing Church opposed the German Christians' emphasis on race, though it too did not escape the antisemitism that pervaded most of German society in the 1930s and early 1940s. The Confessing Church, founded in 1934, evolved out of the Pastors' Emergency League created by Martin Niemöller (1892-1984) and other Protestant leaders in 1933. This group emerged in opposition to the German Christians' attempt to impose the "Aryan Paragraph" on the church and more generally in opposition to the German Christians' support for the centralization of the Protestant church under the Third Reich's control. The German Christians summarized the Aryan Paragraph as it pertained to the church as follows:

Those of non-Aryan descent or married to someone of non-Aryan descent may not be called as clergy or officials in the general church administration. Clergy or officials who marry a person of non-Aryan descent are to be dismissed. Who counts as a person of non-Aryan descent is to be determined by the regulations accompanying the laws of the Reich (Solberg 2015, p. 57). 
The Aryan Paragraph was originally a provision of the April 1933 Reich Civil Service Law that had banned the employment of civil servants of "non-Aryan" ancestry. The Nazi regime had deliberately avoided imposing this ban on Christian clergy - even though they were in fact civil servants paid by the state-to avoid stirring up clerical opposition (Solberg 2015, pp. 53-54). However, the German Christians demanded that the law include clergy. Thanks to their success in the church elections of July 1933, they were able to impose the Aryan Paragraph first on the Prussian Synod in September 1933 and then on the newly-created national Protestant church as a whole.

All those who joined the Pastors' Emergency League, which became the Confessing Church in 1934, were asked to pledge to be "bound only by Holy Scripture and by the confessions of the Reformation" and to "bear witness that the application of the Aryan paragraph in the area of the church of Christ is an infringement upon such a confessional position" (Solberg 2015, p. 55). In principle, the position of Niemöller and the Pastors' Emergency League was a clear-cut rejection of the racial antisemitism of both the Nazis and the German Christians. However, in practice, the situation was anything but clear-cut. Some pastors who joined the League crossed out the article that stated that the Aryan Paragraph was a "violation" of the "confessions of the Reformation." One local branch of the Pastors' Emergency League refused to accept a "non-Aryan" pastor. This decision was reversed thanks to the pastor's appeal to Martin Niemöller. Then another pastor protested this reversal (Barnett 1992, p. 129).

Even Martin Niemöller's own view of baptized Jews in the 1930s suggests that his opposition to the "Aryan paragraph" was rooted in his desire to preserve the church's independence rather than in opposition to racial antisemitism. "Whether it's congenial to us or not," he declared, "we have to recognize the converted Jews as fully entitled members through the Holy Spirit.... This recognition demands of us a high measure of self-discipline as a people who have had a great deal to bear under the influence of the Jewish people, so that the wish to be freed from this demand is understandable" (Barnett 1992, p. 130).

Despite being opposed to the Aryan Paragraph in principle, Niemöller argued "non-Aryans" should avoid seeking positions of leadership in the church so as not to give offense (Paldiel 2006, p. 41). In a 1935 sermon, he described the Jews as "a highly gifted people which produces idea after idea for the benefit of the world, but whatever it takes up becomes poisoned, and all that it ever reaps is contempt and hatred because ever and anon the world notices the deception and avenges itself in its own way" (Paldiel 2006, p. 40). ${ }^{9}$

Niemöller's antisemitism was commonplace in the Confessing Church (Baranowski 1999). Otto Dibelius (1880-1967), another prominent leader of the movement, sent the following Easter message to the pastors in his district in 1928 (before the Confessing Church existed):

My dear brothers!

All of us will not only understand but have complete sympathy for the final motivations behind the völkisch movement. Despite the evil ring that the word has acquired in many cases, I have always considered myself an anti-Semite. It cannot be denied that Judaism plays a leading role in all the corruptive phenomena of modern civilization.

God bless us Christians and our Easter proclamation! (Gerlach 2000, p. 14)

The adjective völkisch, from the noun Volk, can be translated as "ethno-national," or "racial-national." Like Volk, it was a basic term in both the Nazi and German Christian lexicon. Völkisch movements stressed the racial identity of the German people, from which Jews were excluded.

On 1 April 1933, the Nazi regime carried out a boycott of Jewish businesses and professionals to protest what it saw as unfair criticism of its treatment of Jews by the international press, which it

9 For more on Niemöller and his post-war transformation, see United States Holocaust Memorial Museum. n.d. "Martin Niemöller: Biography." Holocaust Encyclopedia. https://www.ushmm.org/wlc/en/article.php?ModuleId=10007391 (accessed on 5 December 2017). 
viewed as controlled by Jews. Nazi Storm Troopers stood in front of Jewish-owned stores and the offices of Jewish doctors and lawyers to keep customers away. The Star of David was painted across thousands of doors and windows. Signs were posted saying "Don't Buy from Jews" and "The Jews Are Our Misfortune." In many cases, Jews were attacked and the police did not intervene. ${ }^{10}$ Dibelius's comment on all of this was published in a Protestant newsletter on 4 April: "The last fifteen years in Germany have strengthened Jewry's influence to an extraordinary degree. The number of Jewish judges, Jewish politicians, and Jewish civil servants in influential positions has grown measurably. Public sentiment turns against this" (Gerlach 2000, p. 14). On 9 April, Dibelius blamed the international condemnation of the 1 April boycott on "Jewry's international connections." In this same article he recommended closing Germany's eastern border against Jews as a defensive measure and he appealed to German "steadfastness ... that will not succumb to an alien race" (Gerlach 2000, p. 15).

Another prominent leader of the Confessing Church was Theophil Wurm (1868-1953), Bishop of Wurttemberg. Wurm, like many others, had left the German Christians to join the Confessing Church because he disapproved of the Nazi regime's attempt to put all Protestant churches under their control. He incurred Hitler's wrath for condemning the Third Reich's euthanasia program for those Germans deemed physically or mentally defective (Ericksen 2010, p. 254). However, he never came to the defense of the Jews. In a January 1949 letter to Protestants preparing a statement about the Holocaust, Wurm wrote:

Can anyone in Germany speak about the Jewish question without mentioning how Jewish literature sinned against the German people through its mockery of all that is holy, since the days of Heinrich Heine? Or of the suffering endured in numerous regions by German farmers at the hands of Jewish money-lenders? And if one wants today to speak out against antisemitism, can one remain silent on the misfortune caused by the Occupying Forces, who have given power to emigré Jews, so that they might give expression to their understandable feelings of rage? (Ericksen and Heschel 2004, p. 313).

Dietrich Bonhoeffer (1906-1945) was a much more outspoken critic of the Aryan Paragraph than most other members of the Confessing Church. Yet even he could not escape the antisemitism that pervaded German society—and the German church—in the 1930s. In 1933, shortly after the 1 April boycott of Jews and Jewish businesses, he finished writing an article entitled "The Church and the Jewish Question." In this article, Bonhoeffer wrote: "Without a doubt the Jewish question is one of the historical problems with which the state must deal, and without a doubt the state is justified in blazing new trails here" (Baranowski 1999, p. 101). He stressed that the church did not have the right to challenge the state regarding how it dealt with "the Jewish question," yet he also stated that there were times when the church did have the right to challenge the state when it committed an injustice. He expressed sympathy for the Jews being persecuted by Hitler's regime, yet he also said that Jewish suffering was punishment for having killed Jesus Christ and that the only real solution to the "Jewish question" was conversion to Christianity (Barnes 1999, pp. 114-17). There is no evidence that he ever repudiated these views (Paldiel 2006, pp. 38-40). ${ }^{11}$

\section{Germany's Catholics and the Holocaust}

In 1937, Germany's Catholic bishops published a Handbook of Contemporary Religious Questions to guide the country's Catholics. The handbook declared that Marxism was "the materialistic socialism founded primarily by the Jew Karl Marx" and Bolshevism was "an Asiatic state despotism, in point of

10 United States Holocaust Memorial Museum. n.d.: Boycott of Jewish Businesses. Holocaust Encyclopedia. https: / / www. ushmm.org/wlc/en/article.php?ModuleId=10005678\# (accessed on 4 December 2017).

11 Scholars have been debating Bonhoeffer's attitude toward Jews for decades with Protestant scholars tending to view him as a martyr and a saint. (He was executed in 1945 for being involved in a plan to assassinate Hitler). Jewish scholars have generally tended to be more critical. Thus, Stanley Rosenbaum has referred to Bonhoeffer as "the best of a bad lot," (Rosenbaum 1981, p. 306). It is difficult to imagine a Protestant scholar saying this (Barnes 1999; Haynes 2006). 
fact in the service of a group of terrorists led by Jews." According to this Catholic handbook, no people could avoid the "clash between its natural tradition and Marxism which is opposed to national ties and led mostly by Jewish agitators and revolutionaries." The handbook also informed its Catholic readers that that most of the decadent and un-German developments in art since the nineteenth century had been the work of "the uprooted and atheistically perverted Jew," or those under Jewish influence (Lewy 1999, pp. 130-32). The article on "Race" in the handbook stated:

Every people bears itself the responsibility for its successful existence, and the intake of entirely foreign blood will always represent a risk for a nationality that has proven its historical worth. Hence, no people may be denied the right to maintain undisturbed their previous racial stock and to enact safeguards for this purpose. The Christian religion merely demands that the means used do not offend against the moral law and natural justice (Lewy 1999, pp. 130-31).

The bishops' handbook does not explain precisely how one preserves "racial stock" without offending "against the moral law and natural justice."

The rhetoric of the Catholic Handbook of Contemporary Religious Questions was representative of how German Catholic clerics described Jews in the 1930s. In 1933, the prominent Catholic theologian Karl Adam said Germany needed to eliminate the "Jewish mentality" from the press, literature, science, and art-although "the Christian conscience must insist that these legal ordinances be implemented in a spirit of justice and love" (Lewy 1999, p. 132). Once again, one wonders how all of this could be done "in a spirit of justice and love." Bishop Hilfrich of Limburg admitted that Jesus had been a Jew in his pastoral letter for Lent 1939, but he insisted that "the Christian religion has not grown out of the nature of this people, that is, is not influenced by their racial characteristics." He added the usual assertion that the Jews had killed Jesus and had been cursed by God ever since (Lewy 1999, p. 132). Once again, we see traditional Christian hostility toward the Jew effortlessly meshed with racial antisemitism.

The idea that the "Jewish mentality" should be excluded from German society "in a spirit of justice and love" was a common theme in the Catholic literature of the 1930s. In 1930, the Jesuit Gustav Gundlach, wrote that antisemitism directed against the "exaggerated and harmful influence" of the Jews was allowed so long as it utilized morally admissible means. In 1931, Bishop Buchberger of Regensburg wrote that, while he while he opposed "racialism" in principle, he concluded that it was "justified self-defense" to avoid the rule of "overly powerful Jewish capital" (Lewy 1999, p. 130). Similarly, in a sermon he gave on 31 December 1933, Cardinal Michael Faulhaber said the Church did not have "any objection to the endeavor to keep the national characteristics of a people as far as possible pure and unadulterated and to foster their national spirit by emphasis upon the common ties of blood which unite them." However, he noted that the Church did oppose placing loyalty to one's race above loyalty to the Church. (Lewy 1999, p. 131).

\section{The Vatican and the Jews}

The German Catholic rhetoric about "the Jewish question" under Nazi rule was reminiscent of the Vatican's rhetoric on the same topic from the late nineteenth century until Nazi Germany's defeat. This is obvious from the kind of articles that appeared in the Vatican's Jesuit journal Civiltà Cattolica during this period. Every article in each issue of this journal had to be approved by the Vatican's secretary of state before publication and each issue had to reflect the views of the current pope (Kertzer 2001, p. 135).

In 1880, Civiltà Cattolica published an article that declared: "Oh how wrong and deluded are those who think that Judaism is just a religion, like Catholicism, Paganism, Protestantism, and not in fact a race, a people, a nation! ... For the Jews are not only Jews because of their religion ... they are Jews also and especially because of their race" (Kertzer 2001, p. 137). In 1897, Civiltà Cattolica declared: "The Jew remains always in every place immutably a Jew. His nationality is not in the soil where he is born, nor in the language that he speaks, but in his seed" (Kertzer 2001, p. 146). 
In 1893, Civiltà cattolica published an article entitled "Jewish Morality" by the Jesuit Severio Rondina. According to Father Rondina, "the Jewish nation"

does not work, but traffics in the property and the work of others; it does not produce, but lives and grows fat with the products of the arts and industry of the nations that give it refuge. It is the giant octopus that with its oversized tentacles envelops everything. It has its stomach in the banks ... and its suction cups everywhere: in contracts and monopolies, ... in postal services and telegraph companies, in shipping and in the railroads, in the town treasuries and in state finance. It represents the kingdom of capital ... the aristocracy of gold .... It reigns unopposed.

Father Rondina went to assert that:

With religious liberty proclaimed, and citizenship conceded even to the Jews, the Jews took advantage of it ... to become our masters. Indeed, today it is the stock market that has political control, and this is in the hands of the Jews. What governs is Masonry, and this too is directed by the Jews. What shapes and reshapes public opinion is the press, and this also is in large part inspired and subsidized by the Jews.

Father Rondina's explanation for "the ceaseless war that Judaism wages against other nations, especially those that are Christian" is that it is caused by the Jews' "hatred of Christianity, a hatred that is imposed on the Jews by their laws, and that goes so far as to justify every sort of crime against us" (Kertzer 2001, p. 145).

Such articles continued to appear in Civiltà cattolica throughout the 1930s until the spring of 1943, when a German victory in World War II seemed increasingly unlikely (Favret and Contreras 2004, p. 221; Passelecq and Suchecky 1997, pp. 123-36). Thus in 1938, an article by Mario Barbera stated: "The Judaic question will remain unresolved, because, as all agree-even those most kindly disposed toward the Jews - their corrupt messianism, that is, their fatal craving for worldwide financial and political domination, is the true cause that makes Judaism a font of disorders and a permanent danger for the world" (Kertzer 2001, p. 278). At times, however, Father Barbera did make a point of distinguishing between "good" Catholic antisemitism and "bad" racist antisemitism. Referring to the Hungarian Catholic Action's demand that the civil rights of Jewish Hungarians be revoked, Father Barbera wrote, on 29 May 1938, that "the antisemitism of the Hungarian Catholics is not vulgar, fanatical antisemitism, nor racist antisemitism; it is a movement in defense of the national traditions and the true liberty and independence of the Magyar people" (Favret and Contreras 2004, pp. 325-26). Hungary's Jews presumably saw the situation somewhat differently.

\section{Conclusions}

The distinction between Nazi and fascist racial antisemitism and traditional Christian hatred of the Jew is real. The fact that a distinction is not always clear-cut does not mean it does not exist. Christian clergy repeatedly objected to Nazi and fascist attempts to treat Jewish converts to Christianity as Jews-while usually displaying little or no concern for Jews who had not converted Moreover, Christian clergy did often criticize Nazi and fascist attempts to make loyalty to one's race more important than loyalty to one's religion (Favret and Contreras 2004, pp. 325-26). One cannot account for all of this if one assumes that racial and religious antisemitism are the same thing. More generally, one cannot analyze the changing relationship between religious and racial antisemitism over the course of history if one assumes they are identical.

That said, the boundary between religious and racial antisemitism has often been blurry and porous. From the late nineteenth century until the defeat of Nazi Germany in 1945, Christian clergy often described Jews as a race. This emphasis on race is not a new phenomenon. One thinks of the Inquisition and its emphasis on the "purity of blood" (limpieza de sangre) (Traverso 2010, pp. 269-75). In 1593, Catholics of Jewish ancestry were barred from becoming Jesuits. This requirement was 
gradually made more lenient. In 1923, the twenty-seventh General Congregation of the Society of Jesus passed a resolution declaring: "The impediment of origin extends to all who are descended from the Jewish race, unless it is clear that their father, grandfather, and great-grandfather have belonged to the Catholic Church." The Jesuits finally did away with this restriction at their twenty-ninth General Congregation, which avoided any mention of Jewish ancestors, but they did refer to "the cautions to be exercised before admitting a candidate about whom there is some doubt as to the character of his hereditary background." This was in 1946 (Carroll 2001, pp. 382-83). Nevertheless, the Catholic Church has always sought to convert Jews to Christianity (Michael 2008). Hitler never tried to get Jews to join the Nazi party.

Aside from the issue of racial vs. religious antisemitism, we find in both Nazi and modern Christian clerical rhetoric many of the classical themes of modern antisemitism. Both portray the Jew as a communist and as a capitalist exploiting Gentiles/Christians. Both refer to Jewish plans to dominate the world. Both refer to Jews as undermining traditional (Christian) values. Additionally, in both, we find such themes meshed with traditional Christian images of the Jew as a spiritually blind, materialistic Christ-killer (Passelecq and Suchecky 1997, pp. 123-36). Those who suggest that the Holocaust was a strictly secular phenomenon for which Christianity and the Christian church are in no way responsible are mistaken. It is true that Hitler and other leading Nazis were not primarily motivated by traditional Christian hatred of the Jew. However, they exploited this hatred very effectively-and it was there to be exploited. Moreover, the church played an important role in this exploitation. The church also absorbed and disseminated much of the secular antisemitism that pervaded Europe in the decades before the Holocaust and during the twelve years of Hitler's rule. If all the Christian clergy of Europe had defied Hitler and declared that the mass murder of the Jews was an abomination that had to stop, it might have stopped. A few heroic Christian clerics did risk their lives to save the lives of Jews, but most did not.

Christian clergy had been vilifying Jews for close to two millennia and they had been calling for the curtailing or elimination of Jewish influence for most of the first three and a half decades of the twentieth century. It was thus very hard for most of them to criticize governments for doing what they wanted done. Of course, few went so far as to endorse mass murder. However, few publicly condemned it either. To refer to the Holocaust as a strictly secular phenomenon without mentioning such facts is to distort history.

Conflicts of Interest: The author declares no conflict of interest.

\section{References}

Armstrong, Karen. 2014. Fields of Blood: Religion and the History of Violence. New York: Alfred A. Knopf.

Baranowski, Shelley. 1999. The Confessing Church and Antisemitism: Protestant Identity, German Nationhood, and the Exclusion of the Jews. In Betrayal: German Churches and the Holocaust. Edited by Robert P. Ericksen and Susannah Heschel. Minneapolis: Augsburg Fortress Publishers, pp. 90-109.

Barnes, Kenneth C. 1999. Dietrich Bonhoeffer and Hitler's Persecution of the Jews. In Betrayal: German Churches and the Holocaust. Edited by Robert P. Ericksen and Susannah Heschel. Minneapolis: Augsburg Fortress Press, pp. 110-28.

Barnett, Victoria. 1992. For the Soul of the People: Protestant Protest Against Hitler. Oxford and New York: Oxford University Press.

Bergen, Doris L. 1996. Twisted Cross: The German Christian Movement in the Third Reich. Chapel Hill and London: University of North Carolina Press.

Bergen, Doris L. 2007. Nazism and Christianity: Partners and Rivals? A Response to Richard Steigmann-Gall, the Holy Reich. Nazi Conceptions of Christianity, 1919-1945. Journal of Contemporary History 42: 25-33. [CrossRef]

Berger, Alan L. 2015. Post-Holocaust Jewish-Christian Dialogue: After the Flood, before the Rainbow. Lanham: Lexington Books. 
Brog, David. 2010. In Defense of Faith: The Judeo-Christian Idea and the Struggle for Humanity. New York: Encounter Books.

Bucher, Rainer. 2011. Hitler's Theology a Study in Political Religion. London and New York: Continuum International Publishing.

Carroll, James. 2001. Constantine's Sword: The Church and the Jews: A History. Boston: Houghton Mifflin.

Ericksen, Robert P. 2010. Protestants. In Oxford Handbook of Holocaust Studies. Edited by Peter Hayes and John K. Roth. Oxford: Oxford University Press, pp. 250-64.

Ericksen, Robert P. 2012. Complicity in the Holocaust: Churches and Universities in Nazi Germany. Cambridge and New York: Cambridge University Press.

Robert P. Ericksen, and Susannah Heschel, eds. 1999a. Betrayal: German Churches and the Holocaust. Minneapolis: Fortress Press. In Betrayal: German Churches and the Holocaust. Minneapolis: Fortress Press.

Ericksen, Robert P., and Susannah Heschel. 1999b. Introduction. In Betrayal: German Churches and the Holocaust. Edited by Robert P. Ericksen and Susannah Heschel. Minneapolis: Augsburg Fortress Publishers, pp. 1-21.

Ericksen, Robert P., and Susannah Heschel. 2004. The German Churches and the Holocaust. In The Historiography of the Holocaust. Edited by Dan Stone. Basingstoke and New York: Palgrave Macmillan, pp. 296-318.

Favret, Jeanne, and José Contreras. 2004. Le Christianisme et ses Juifs: 1800-2000. Paris: Seuil.

Feldman, Matthew, Marius Turda, and Tudor Georgescu. 2008. Clerical Fascism in Interwar Europe. London: Routledge.

Gailus, Manfred. 2007. A Strange Obsession with Nazi Christianity: A Critical Comment on Richard Steigmann-Gall's the Holy Reich. Journal of Contemporary History 42: 35-46. [CrossRef]

Gerlach, Wolfgang. 2000. And the Witnesses Were Silent: The Confessing Church and the Persecution of the Jews. Lincoln: University of Nebraska Press.

Goldhagen, Daniel Jonah. 2002. A Moral Reckoning: The Role of the Catholic Church in the Holocaust and its Unfulfilled Duty to Repair. New York: Alfred A. Knopf.

Haynes, Stephen R. 2006. The Bonhoeffer Legacy: Post-Holocaust Perspectives. Minneapolis: Fortress Press.

Hedges, Chris. 2008. I Don't Believe in Atheists. New York: Free Press.

Heschel, Susannah. 2008. The Aryan Jesus: Christian Theologians and the Bible in Nazi Germany. Princeton: Princeton University Press.

Heschel, Susannah. 2011. Historiography of Antisemitism versus Anti-Judaism: A Response to Robert Morgan. Journal for the Study of the New Testament 33: 257-79. [CrossRef]

Hexham, Irving. 2007. Inventing 'Paganists': A Close Reading of Richard Steigmann-Gall's the Holy Reich. Journal of Contemporary History 42: 59-78. [CrossRef]

Katz, Steven T. 1994. The Holocaust in Historical Context. Vol. 1, the Holocaust and Mass Death before the Modern Age. New York and Oxford: Oxford University Press.

Kertzer, David I. 2001. The Popes against the Jews: The Vatican's Role in the Rise of Modern Anti-Semitism. New York: Knopf.

Levine, Amy-Jill. 2006. The Misunderstood Jew: The Church and the Scandal of the Jewish Jesus. San Francisco: HarperSanFrancisco.

Lewy, Guenter. 1999. Pius XII, the Jews, and the German Catholic Church. In Betrayal: German Churches and the Holocaust. Edited by Robert P. Ericksen and Susannah Heschel. Minneapolis: Augsburg Fortress Publishers, pp. 129-48.

Limbaugh, Rush H. 1992. The Way Things Ought to Be. New York: Pocket Books.

Michael, Robert. 2008. A History of Catholic Antisemitism: The Dark Side of the Church, 1st ed.New York: Palgrave Macmillan.

Munson, Henry. 2005. Religion and Violence: A Review Article. Religion 35: 223-46. [CrossRef]

Paldiel, Mordecai. 2006. Churches and the Holocaust: Unholy Teaching, Good Samaritans, and Reconciliation. Jersey City: Ktav.

Passelecq, Georges, and Bernard Suchecky. 1997. The Hidden Encyclical of Pius XI. New York: Harcourt Brace.

Piper, Ernst. 2007. Steigmann-Gall, the Holy Reich. Journal of Contemporary History 42: 47-57. [CrossRef]

Rosenbaum, Stanley R. 1981. Dietrich Bonhoeffer: A Jewish View. Journal of Ecumenical Studies 18: 301-7.

Sacks, Jonathan. 2015. Not in God's Name: Confronting Religious Violence. London: Hodder \& Stoughton.

Mary M. Solberg, ed. 2015. A Church Undone: Documents from the German Christian Faith Movement, 1932-1940. Minneapolis: Fortress Press. 
Steigmann-Gall, Richard. 2003. The Holy Reich: Nazi Conceptions of Christianity, 1919-1945. New York: Cambridge University Press.

Steigmann-Gall, Richard. 2007. Christianity and the Nazi Movement: A Response. Journal of Contemporary History 42: 185-211. [CrossRef]

Traverso, Enzo. 2010. L'Histoire Comme Champ de Bataille Interpréter Les Violences du XXe Siècle. Paris: La Découverte. Wegner, Gregory Paul. 2002. Anti-Semitism and Schooling under the Third Reich. New York: Routledge Falmer.

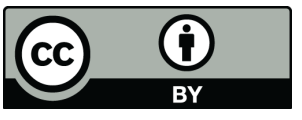

(c) 2018 by the author. Licensee MDPI, Basel, Switzerland. This article is an open access article distributed under the terms and conditions of the Creative Commons Attribution (CC BY) license (http:/ / creativecommons.org/licenses/by/4.0/). 